\title{
Paleo-ecological analyses to assess long-term environmental effects of pearl farming in Western Australia
}

\author{
Dongyan Liu ${ }^{1, *}$, Yajun Peng ${ }^{1,2}$, John K. Keesing ${ }^{3,4}$, Yujue Wang ${ }^{1}$, Pierre Richard ${ }^{5}$ \\ ${ }^{1}$ Key Laboratory of Coastal Zone Environmental Processes and Ecological Remediation, \\ Yantai Institute of Coastal Zone Research, Chinese Academy of Sciences, 264003 Yantai, Shandong, PR China \\ ${ }^{2}$ University of the Chinese Academy of Sciences, 100049 Beijing, PR China \\ ${ }^{3}$ CSIRO Oceans and Atmosphere, Private Bag 5, Wembley 6913, Australia \\ ${ }^{4}$ The Western Australian Marine Science Institution, Perth, Australia \\ ${ }^{5}$ Littoral, Environment et Sociétés, UMR 7266 CNRS-Université de La Rochelle, 2 rue Olympe de Gouges, 17000 La Rochelle, \\ France
}

\begin{abstract}
Small environmental disturbances accumulating over a long period of time may cause a regime shift in marine ecosystems, particularly in sensitive oligotrophic waters. Pearl oyster aquaculture, which has a 50 yr history in Australia, has been regarded as an anthropogenic activity with low environmental risk. To assess the long-term environmental effects of pearl oyster farming, sediment cores taken in Cygnet Bay, Western Australia, were used to reconstruct environmental processes covering an approximately $90 \mathrm{yr}$ period. Biogeochemical parameters in sediment cores from inside and outside a pearl farming area displayed contrasting characteristics over time. Total organic carbon, total nitrogen, biogenic silica (BSi), and fine-grained sediment at the farming site displayed significant increases with the expansion of oyster stocking. In contrast, only small variations in response to climatic signals (rainfall and temperature) occurred over time in the cores outside the farm. The variation in the $\mathrm{C}: \mathrm{N}$ ratio, $\delta^{13} \mathrm{C}$ and $\delta^{15} \mathrm{~N}$ ranges over time suggested that increased organic matter was mainly contributed by autochthonous sources rather than terrestrial input. The sequential $t$-test for a regime shift detected approximately 2 - to 3 -fold increases in organic matter, 1 - to 5 -fold increases in silt proportion and 2- to 5 -fold increases in $\mathrm{BSi}$ concentrations after pearl oyster farming, in contrast to the control site. The rapid development of modern long-line culture since the late 1980s is presumed to have been the dominant driver of environmental changes in sediments. The results provide insight into the magnitude of environmental change which can occur over decades as a result of even minimal anthropogenic activity.
\end{abstract}

KEY WORDS: Pearl oyster farming · Paleo-ecology · Sediment cores · Biogenic silica $\cdot$ Cygnet Bay · Western Australia

Resale or republication not permitted without written consent of the publisher

\section{INTRODUCTION}

Large-scale and intensive bivalve farming can significantly impact aquatic environments by changing a series of physical and chemical conditions, such as reducing tidal current, accelerating organic accumulation, and altering sediment properties (Plew et al.
2005, Callier et al. 2008, Dumbauld et al. 2009). The impact levels depend on a set of integrative factors (Read \& Fernandes 2003, Dumbauld et al. 2009), including the species involved (e.g. oyster, mussel or clam), culture methods (e.g. cages or rafts), density, sites, scales, and aquaculture history. For example, compared with mussel aquaculture, which contrib- 
utes significantly to sediment accumulation and nutrient input (Prins \& Smaal 1994, Strang 2003), pearl oyster aquaculture displays much lower impacts on sediment properties and nutrient concentrations due to its low density culture and lack of artificial feed or chemicals (Cheney et al. 1995, Yokoyama 2002, Wells \& Jernakoff 2006, Gaertner-Mazouni et al. 2012).

However, small environmental changes accumulating over a long period of time can still cause a regime shift in an ecosystem (Lees et al. 2006, Andersen et al. 2009), and the underlying processes and changing rates can only be realized by careful analysis of long-term continuous observation data. For example, Sarà et al. (2011) found that nutrient and chlorophyll a concentrations in the Gulf Castellammare, Italy have been steadily increasing since the establishment of aquaculture facilities in 1999, although they had not reached a eutrophic status. In addition, hydrodynamic conditions at aquaculture sites are important for determining the rate of change. The rate of impact is a slower process at sites with high current (average velocity $>0.1 \mathrm{~m} \mathrm{~s}^{-1}$ and maximum velocity $>0.3 \mathrm{~m} \mathrm{~s}^{-1}$; da Costa \& Nalesso 2006), whereas it is faster at sites with low current (average velocity $<0.05 \mathrm{~m} \mathrm{~s}^{-1}$ and maximum velocity $<0.1 \mathrm{~m} \mathrm{~s}^{-1}$; Hartstein \& Rowden 2004, Callier et al. 2008). In contrast to the time span of marine aquaculture activity supporting human life, our ability to understand environmental effects of aquaculture is limited to knowledge on decadal scales. Continuous long-term monitoring data are expensive and rare, and they usually record environmental information after the impact of human activities. The development of paleo-ecological methods has made it possible to acquire a chronological footprint of past environmental change, and the time span can extend from decades through centuries to millennia (Meyers 1997, Meyers \& Teranes 2001, Pancost \& Boot 2004). A number of geochemical proxies (e.g. stable carbon and nitrogen isotopes, biogenic silica, lipid and biomarkers) deposited in the sediments have been used to reconstruct environmental events, such as eutrophication, industrialization, and climate change (Andersen et al. 2004, Turner et al. 2006, Dale 2009, Liu et al. 2013), and these studies not only provide effective environmental information, but also help to minimize long-term monitoring effort and costs.

The organic matter preserved in sediments can provide powerful data for interpreting coastal eutrophic processes, and the analysis of stable isotopes of carbon and nitrogen $\left(\delta^{13} \mathrm{C}\right.$ and $\left.\delta^{15} \mathrm{~N}\right)$ makes it possible to elucidate the source and fate of organic matter (Meyers 1994). In transitional waters (e.g. coasts and estuaries), organic matter sources are generally a mixture of allochthonous (e.g. river inputs) and autochthonous sources (e.g. marine primary production). They carry their source-specific signatures and display these in the values of $\delta^{13} \mathrm{C}$ and $\delta^{15} \mathrm{~N}$. For example, a typical range of $\delta^{13} \mathrm{C}$ values for terrestrial $\mathrm{C}_{3}$ plants is from -26 to $-28 \%$ and from -19 to $-21 \%$ for marine phytoplankton (Fry \& Sherr 1984, Meyers 1997). A mixture of marine and terrestrial organic matter could result in a $\delta^{13} \mathrm{C}$ value of approximately $-23 \%$ (Pancost $\&$ Boot 2004). The value of $\delta^{15} \mathrm{~N}$ originating from marine nitrate generally ranges from 3 to $6 \%$; however, sewage and manure can significantly elevate this value to 10 to $25 \%$ (McClelland \& Valiela 1998, Savage 2005). C:N ratios can be another potential indicator for elucidating organic matter source. For example, a ratio of 5 to 7 is measured for marine-derived organic matter (Redfield et al. 1963), and $>12$ for terrestrial-derived organic matter (Meyers 1997). However, mineralization, oxidation and significant fractions of inorganic nitrogen can impact C: $\mathrm{N}$ ratios and limit their usefulness as source indicators (Andrews et al. 1998, Kuwae et al. 2006). Thus, the application of multiple proxies $\left(\delta^{13} \mathrm{C}, \delta^{15} \mathrm{~N}\right.$, and C:N ratios) is important for verifying the organic matter source. Biogenic silica (BSi) stored in sediment is an important proxy representing siliceous marine organisms (e.g. diatoms, radiolaria, siliceous sponges, and silicoflagellates), particularly for diatoms, a major phytoplankton group which makes a significant contribution to marine primary production and also acts as a sensitive indicator responsive to varied environmental conditions (DeMaster et al. 1991, DeMaster 2002, Smol \& Stoermer 2010). Silicon is an essential element for the growth of diatoms. In water bodies dominated by diatoms, the BSi concentration in sediment can be an important proxy indicating modern or paleo-productivity (Bernárdez et al. 2005, Krause et al. 2011). If we can form an environmental picture combining BSi information with organic matter composition, it is possible, to a certain degree, to assess the impact of past environmental changes (e.g. climate and hydrodynamic changes, nutrient cycling) on siliceous phytoplankton.

In this study, we applied paleo-ecological methods for tracking the long-term environmental impact of pearl oyster farming in Cygnet Bay, Kimberley, Western Australia (see Fig. 1). Farming of the silver- or gold-lip pearl oyster Pinctada maxima in the Kimberley region has a history of approximately $50 \mathrm{yr}$ and is the foundation of the Australian pearl industry and a major contributor to the world's total South Sea pearl production, with an average annual value of around US\$220 million (Tisdell \& Poirine 2008, McCallum \& 
Prince 2009). Theoretically, the variety of culture apparatus used in pearl oyster farming, such as rafts and panel nets, and harvesting processes could increase the deposition of organic matter, nutrient flux and fouling species in the ecosystem (Forrest et al. 2009, Kishore et al. 2014). Actually, a few investigations (Wells \& Jernakoff 2006, McCallum \& Prince 2009, Jelbart et al. 2011) found only small environmental impacts with low ecological risk, with the reasons attributed to passive farming, low stocking density $(<16250$ shells per square nautical mile) and high current flows. However, the environmental assessment still has some uncertainty because, compared to the 50 yr history of pearl farming, the limited time frame of the studies (as described in the publications above) makes it difficult to recognize the underlying process of environmental change over the course of the pearl farming activities, especially if the environmental change rate is very slow. In this work, a $90 \mathrm{yr}$ environmental record was reconstructed using marine sediment cores to assess the environmental change rate after the initiation of pearl farming in Cygnet Bay.

Cygnet Bay is located in King Sound (see Fig. 1). The Fitzroy River, the largest river draining into King Sound, has a catchment largely in a wilderness setting (Semeniuk \& Brocx 2011) which is sparsely populated (3261 persons living around Derby, Australian Bureau of Statistics 2011) with low density

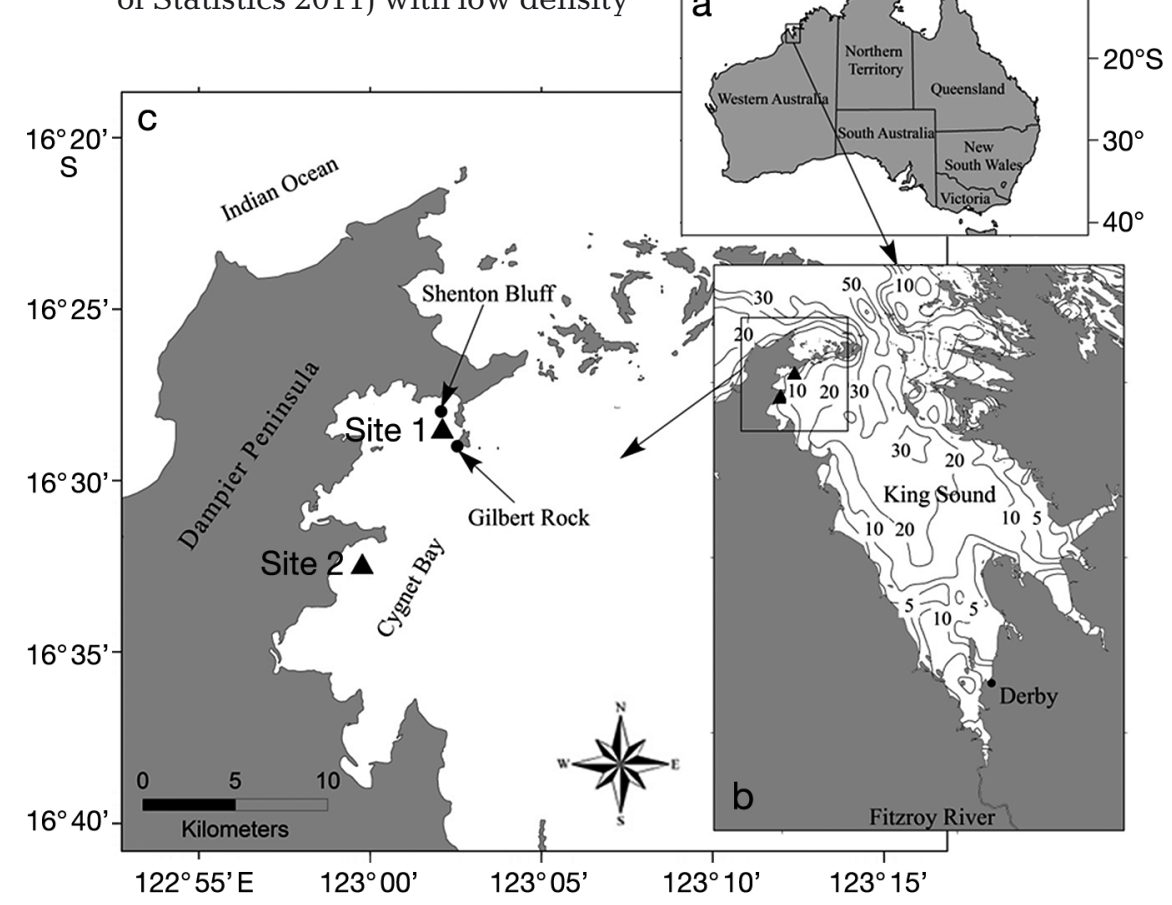

Fig. 1. Location of the study area with (b) water depth (in $\mathrm{m}$ ) and (c) the 2 sampling sites in Cygnet Bay, Kimberley Region, northern Western Australia agriculture. There is a diamond mine currently operating (Ellendale Mine, approximately $120 \mathrm{~km}$ east of Derby) and there was a short-lived gold rush in the 1880s, while lead and silver mining was discontinued in the 1980s. These industries are not thought to have had a major impact on the water quality in King Sound (Centre of Excellence in Natural Resource Management [CENRM] 2010), and Cygnet Bay is more than $150 \mathrm{~km}$ seaward of the entrance of the Fitzroy River into King Sound. Pearl oyster farming is the only significant anthropogenic activity in Cygnet Bay. It was established in the 1960s by the Brown family and is Australia's oldest and longest continually operated pearl farm. This provided an opportunity to assess decadal aquaculture effects without much disturbance from other human activity. Sediment cores were collected at 2 sites, located inside and outside the pearl-farming area, respectively, enabling us to compare their contrasting environmental characteristics over time. Multiple geochemical proxies in the cores, including organic matter, carbon and nitrogen isotopes, biogenic silica, and grain size, were measured to elucidate the underlying processes of environmental change in response to pearl oyster farming. The magnitude of the shift change between the farming site and the control site over time was assessed using a sequential $t$-test for a regime shift (Rodionov 2004), and the impacts of pearl farming and climate change are discussed in relation to the variations in geochemical parameters over time.

\section{MATERIALS AND METHODS}

\section{Study area and core sampling}

Cygnet Bay is a semi-enclosed coastal bay, located in King Sound, in the Kimberley region, which is the northernmost region of Western Australia. It has an approximate area of $150 \mathrm{~km}^{2}$ and an average water depth of $10 \mathrm{~m}$ (Fig. 1). King Sound is the receiving water body of the Fitzroy River catchment and has an average depth of $18 \mathrm{~m}$ (Fig. 1b). It is characterized by a typical semi-arid tropical climatic regime, with an annual temperature range of 20 to $33^{\circ} \mathrm{C}$ and a rainfall range of 600 to $1000 \mathrm{~mm}$, about $70 \%$ of which falls between January and March. Moreover, the evaporation 


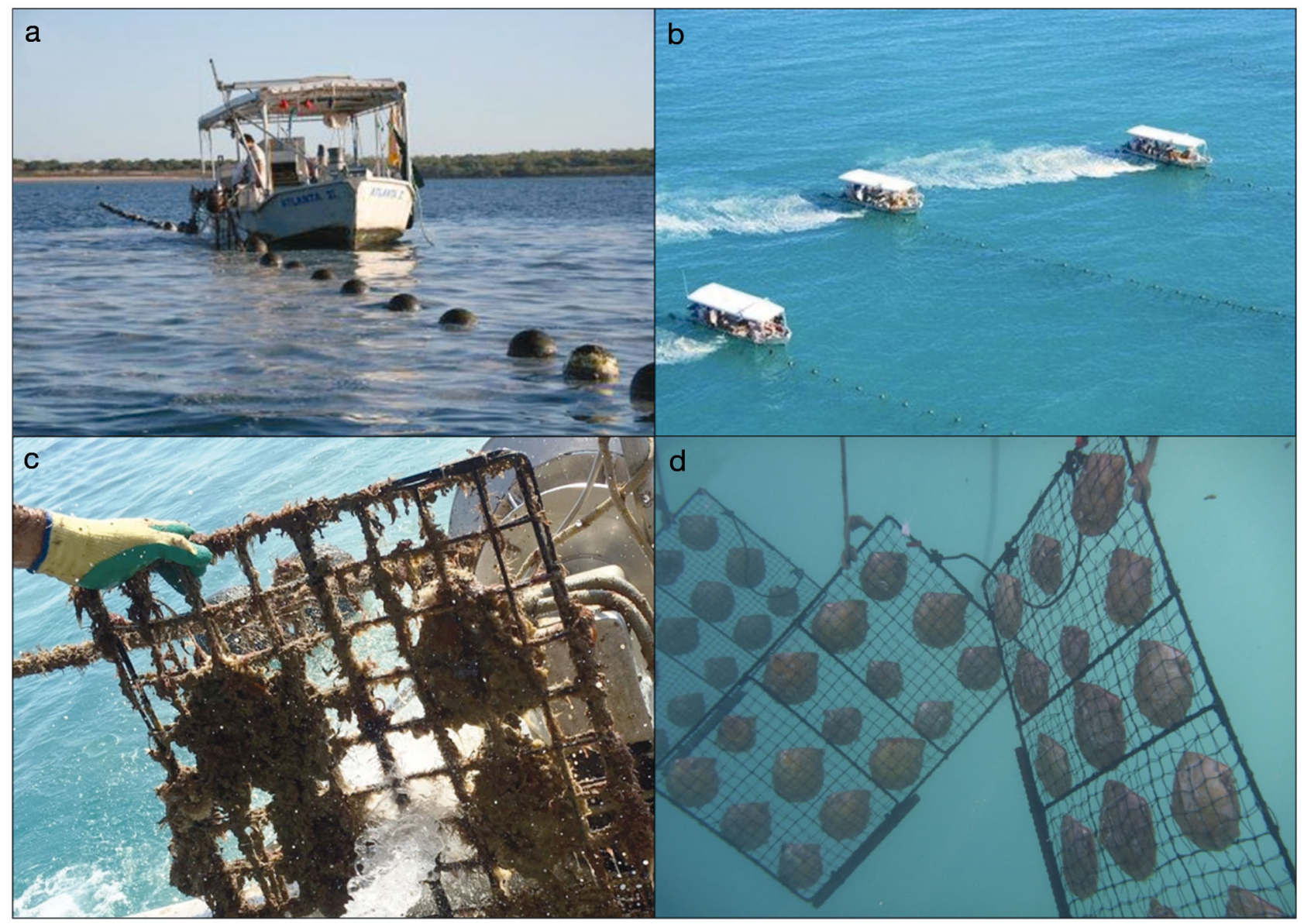

Fig. 2. Modern long-line culture of pearl oysters in Cygnet Bay. (a,b) Cleaning/maintenance vessels tending long lines; (c) biofouling of 8-shell culture cage before cleaning; $($ d) 15-shell culture cages hanging on long line after cleaning

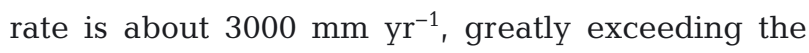
rainfall. King Sound has the second largest tidal range in the world, and hydrodynamic processes are mainly controlled by tide-driven currents (Wolanski \& Spagnol 2003, Semeniuk \& Brocx 2011).The maximum tidal range can reach $11 \mathrm{~m}$ (mean spring range $7.75 \mathrm{~m}$, mean neap range $5.72 \mathrm{~m}$ ), with strong current movement from 2 -way tidal velocities, showing an average of $>0.2 \mathrm{~m} \mathrm{~s}^{-1}$ and a peak flow of $0.75 \mathrm{~m} \mathrm{~s}^{-1}$ (Wolanski \& Spagnol 2003).

Pearl oyster farming is set up within the top 2 to $3 \mathrm{~m}$ of water (total depth ca. $10 \mathrm{~m}$ ) using floating long lines that are approximately $200 \mathrm{~m}$ long and spaced approximately $50 \mathrm{~m}$ apart, occupying approximately $40 \%$ of the bay area. Oysters are suspended in vertically held cages with 8 to 15 oysters per cage (Fig. 2). The industry standard for the stocking density of pearl oysters is no more than 16250 shells per square nautical mile, and no artificial feed or chemicals are required in the culture (Jelbart et al. 2011). The seabed in the study area is soft sediment without any macroalgae or seagrass present, although reef and intertidal habitats elsewhere in Cygnet Bay do support these plant types.

Sediment cores were collected at the 2 sites in November of 2011. Site 1 ( $\left.16^{\circ} 28^{\prime} 28^{\prime \prime} \mathrm{S}, 123^{\circ} 02^{\prime} 06^{\prime \prime} \mathrm{E}\right)$ is in the aquaculture area just west of Shenton Bluff and Gilbert Rock with a water depth of $11.5 \mathrm{~m}$. Site 2 is $8.6 \mathrm{~km}$ southwest of the aquaculture area $\left(16^{\circ} 32^{\prime} 25^{\prime \prime} \mathrm{S}, 122^{\circ} 59^{\prime} 45^{\prime \prime} \mathrm{E}\right)$ with a water depth of $9.8 \mathrm{~m}$ (Fig. 1c). Site 2 is similar to Site 1 in that both are approximately $1.5 \mathrm{~km}$ south of small peninsulas that run from west to east (Fig 1c). At each site, 3 replicate sediment cores with a length of approximately $1 \mathrm{~m}$ each were collected by SCUBA divers using a push core with a $6 \mathrm{~cm}$ internal diameter. The cores were sectioned into sub-samples at $1 \mathrm{~cm}$ intervals and stored in a freezer at $-20^{\circ} \mathrm{C}$ before analysis. To confirm that the replicate cores from each site were similar to each other in sedimentary structure, the difference in median grain size $\left(\mathrm{d}_{50}\right)$, at each $1 \mathrm{~cm}$ interval between 2 cores from each site was com- 
pared using regression analysis, and the result showed that cores were significantly correlated at a $95 \%$ confidence level (see Figs. S1 \& S2 in the Supplement at www.int-res.com/articles/suppl/m552p145 _supp.pdf). Furthermore, the replicate cores from each site were used for different analyses. One was used for chronology and the other was used for geochemical analyses, as described below. The third core was retained frozen as a spare for future analysis and in case of loss of samples during shipping or handling during analysis by third parties. It is acknowledged that in the absence of samples from multiple locations within the culture area (Site 1) and the non-culture area (Site 2), our replicate cores are actually pseudo-replicates.

\section{Core dating}

\begin{abstract}
${ }^{210} \mathrm{~Pb}$ radiometric-dating techniques (Appleby 2001) were used to measure the core ages for the 2 sites. Radiochemical measurements were performed using well-type germanium (Ge) detectors (GWL-120210-S, ORTEC). The ${ }^{210} \mathrm{~Pb}$ and ${ }^{137} \mathrm{Cs}$ activities were measured after correction with standard samples provided by the Chinese Institute of Atomic Energy Research and the University of Liverpool. Based on the relative variations in excess ${ }^{210} \mathrm{~Pb}\left({ }^{210} \mathrm{~Pb}_{\mathrm{ex}}\right)$ concentrations, sedimentation rates were calculated using the Constant Initial Concentration (CIC) model (Appleby 2001).
\end{abstract}

\section{Grain size measurement}

Grain sizes of each core were measured at $1 \mathrm{~cm}$ intervals using a Malvern Mastersizer 2000F Laser Particle Sizer, to obtain the trend. They were classified into 3 groups (less than $4 \mu \mathrm{m}, 4$ to $63 \mu \mathrm{m}$, and larger than $63 \mu \mathrm{m})$ according to Folk's triangle classification and nomenclature (Folk et al. 1970). Prior to the grain-size measurements, small shells visible to the naked eye were removed from the sediments, and then the samples were treated using $10 \% \mathrm{H}_{2} \mathrm{O}_{2}$ and $10 \% \mathrm{HCl}$ to remove organic matter and carbonate, respectively. The samples were then dispersed in a $0.05 \%\left(\mathrm{NaPO}_{3}\right)_{6}$ solution to separate particles for measurement.

\section{Analysis of geochemical parameters}

Freeze-dried sediment samples were homogenized by grinding, and then weighed aliquots were acidified by adding $2 \mathrm{ml}$ of $1 \mathrm{M} \mathrm{HCl}$ to every $100 \mathrm{mg}$ of sample. The acidified samples were dried at $>60^{\circ} \mathrm{C}$ while being flushed with filtered air, then mixed with $1 \mathrm{ml}$ Milli-Q water and freeze-dried again. Samples were weighed again to account for the change in weight occurring during the acid treatment. Aliquots of about $20 \mathrm{mg}$ were weighed into $5 \times 8 \mathrm{~mm}$ tin capsules for the measurements of total organic carbon (TOC), total nitrogen (TN), and carbon and nitrogen isotopes $\left(\delta^{13} \mathrm{C}\right.$ and $\left.\delta^{15} \mathrm{~N}\right)$ using a continuous-flow isotope-ratio mass spectrometer (Delta V Advantage, Thermo Scientific) coupled to an elemental analyzer (Flash EA 1112 Thermo Scientific). These measurements were carried out at the Littoral Environment et Sociétés (LIENSs)-UMR7266, France. The isotopic measurement results are expressed relative to Vienna PeeDee Belemnite and atmospheric $\mathrm{N}_{2}$ for $\delta^{13} \mathrm{C}$ and $\delta^{15} \mathrm{~N}$, respectively. Replicate sample measurements of an acetanilide standard (Thermo Scientific) indicated that the analytical errors were $<0.1 \%$ o for both $\delta^{13} \mathrm{C}$ and $\delta^{15} \mathrm{~N}$. The C:N ratios were determined as mol:mol ratios, which were transformed from the \% TOC and \% TN weight data obtained as part of the stable isotope analyses. Replicate measurements of a certified reference material (Low Organic Content Soil, Elemental MicroAnalysis) indicated analytical errors of $0.025 \%$ and $0.002 \%$ for $\%$ TOC and \% TN, respectively.

The wet alkaline leaching method was used to measure BSi in the sediments (DeMaster et al. 1991, Kamatani \& Oku 2000). Approximately $0.2 \mathrm{~g}$ of freeze-dried and well-ground sediments were used for sample pre-treatment. First, $10 \mathrm{ml}$ of $10 \% \mathrm{H}_{2} \mathrm{O}_{2}$ and $10 \% \mathrm{HCl}$ were added to the samples to remove organic matter and carbonate, respectively, and then the excess hydrochloric acid and peroxide were washed out using Milli-Q water. The wet samples were placed in an oven to dry overnight at $60^{\circ} \mathrm{C}$ and then digested with $2 \mathrm{M} \mathrm{Na}_{2} \mathrm{CO}_{3}$ at $85^{\circ} \mathrm{C}$ for $8 \mathrm{~h}$. It was necessary to gently swirl the samples for homogenization during the digestion processes. At $1 \mathrm{~h}$ intervals, $0.1 \mathrm{ml}$ of alkaline solution was extracted for measurement by the molybdate blue spectrophotometric method using OUXI TU-1810. Replicate measurements indicated that analytical errors were below $0.005 \%$.

\section{Data analysis}

The magnitudes of the shift changes in geochemical parameters over time at the 2 sites were assessed using sequential $t$-test analysis of regime shifts (STARS; Rodionov 2004, Rodionov \& Overland 2005). 

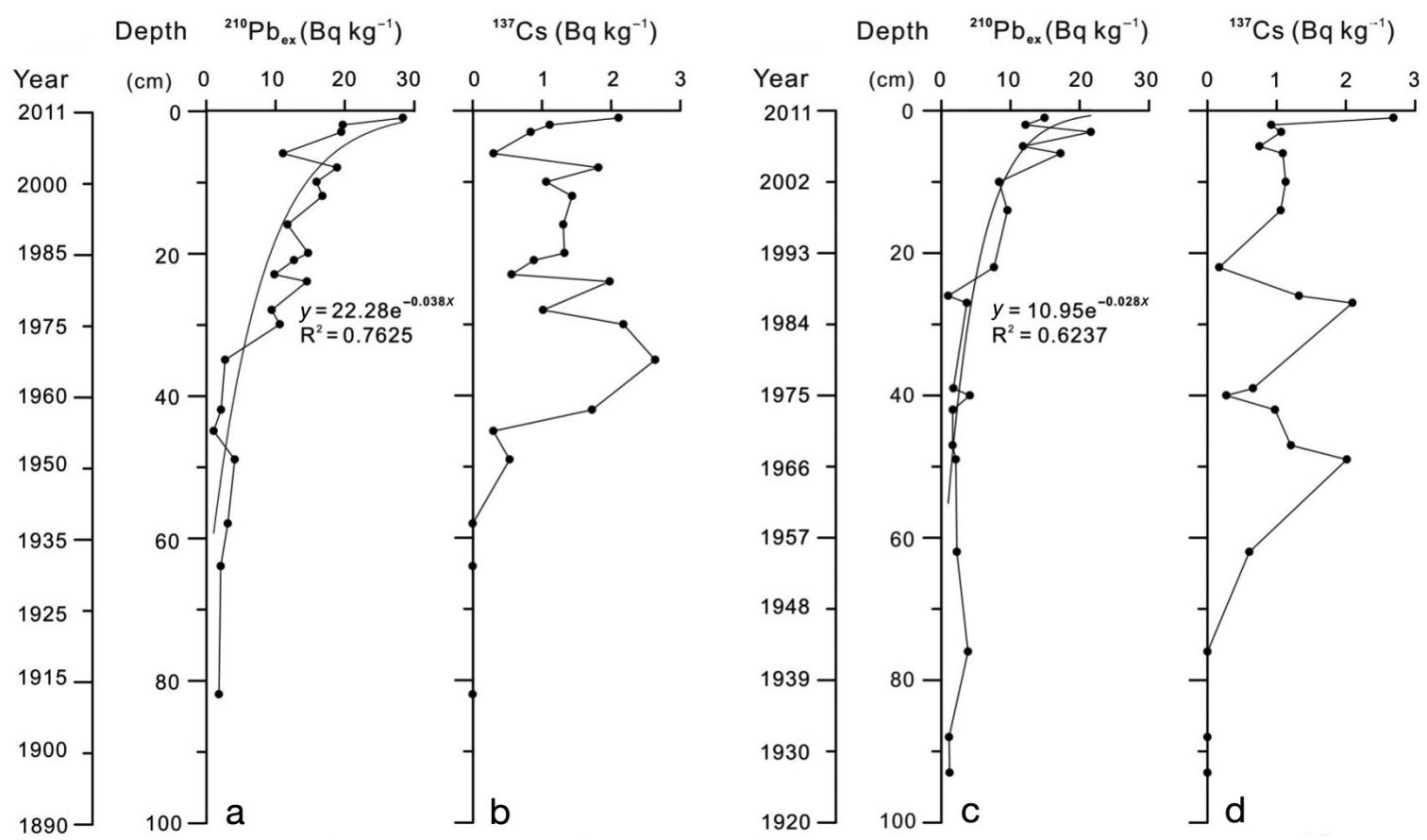

Fig. 3. Profiles of excess ${ }^{210} \mathrm{~Pb}\left({ }^{210} \mathrm{~Pb}_{\mathrm{ex}}\right)$ and ${ }^{137} \mathrm{Cs}$ in the sediment cores from $(\mathrm{a}, \mathrm{b})$ Site 1 and $(\mathrm{c}, \mathrm{d})$ Site 2

The STARS algorithm was converted to VBA for Excel (the analysis software is available for download at www.BeringClimate.noaa.gov). The cut-off length (l) was set to $10 \mathrm{yr}$ and the probability level to $\mathrm{p}=$ 0.05 , representing a significant regime shift. After the shift point was established, the value of the regime shift index (RSI) indicated the magnitude of the shift. For the spatial comparison between the 2 cores, the ratios of geochemical parameters (e.g. $\mathrm{TOC}_{\text {Site } 1} / \mathrm{TOC}_{\text {Site } 2}$ ) were calculated after the interpolation analyses of chronological data using Origin 8.0 software (Mathematics: interp1xy) to reduce asynchronous errors caused by the different sedimentation rates at Site 1 and Site 2.

\section{RESULTS}

\section{Core chronology}

The profiles of ${ }^{210} \mathrm{~Pb}_{\text {ex }}$ concentrations in the 2 cores are shown in Fig. 3a,c. They exhibited an exponential regression pattern and showed some disturbance in surficial sediments. Such disturbance is common in coastal and estuarine sediments, due to physical mixing, bioturbation, and erosion (RuizFernández \& Hillaire-Marcel 2009, Johannessen \& Macdonald 2012). Tidal action and burrowers are regarded as the main impact factors on sedimenta- tion in King Sound (Semeniuk \& Brocx 2011). Sand bubbler crabs and sand tube worms are common organisms causing burrow-mixed sediment in the upper section of cores. Although cyclonic storms are a feature of Australia's tropical regions, their influence on the indented, sheltered gulf embayments in the Kimberley region, like those in our study, is generally limited to abnormally high tides and storm surges, as they are protected from stormmagnified swell and wind waves (see Semeniuk 2011 for detailed explanation of sedimentary dynamics in this region). The CIC model will be prone to large errors if there is significant mixing of surficial sediment, compared with the Constant Rate of Supply (CRS) model (Appleby 2001). The average sedimentation rates were calculated over a time span of approximately 1890 to 2011 at Site 1 $\left(0.82 \mathrm{~cm} \mathrm{yr}^{-1}\right)$ and approximately 1920 to 2011 at Site $2\left(1.11 \mathrm{~cm} \mathrm{yr}^{-1}\right)$.

The ${ }^{210} \mathrm{~Pb}$ geochronology must be validated using at least 1 independent age control (Smith 2001). ${ }^{137} \mathrm{Cs}$ activity is widely used as an independent tracer of coastal sediments, although only $40 \%$ of atmospheric fallout ${ }^{137} \mathrm{Cs}$ (up to $3-5 \mathrm{~Bq} \mathrm{~kg}^{-1}$ ) can be detected in marine sediments from the Australian northern tropical region (Pfitzner et al. 2004, Hollins et al. 2011, Logan et al. 2011). Generally, appreciable ${ }^{137} \mathrm{Cs}$ was first introduced into the environment in 1954 and peaked in 1964 (Amos et al. 2009), but 


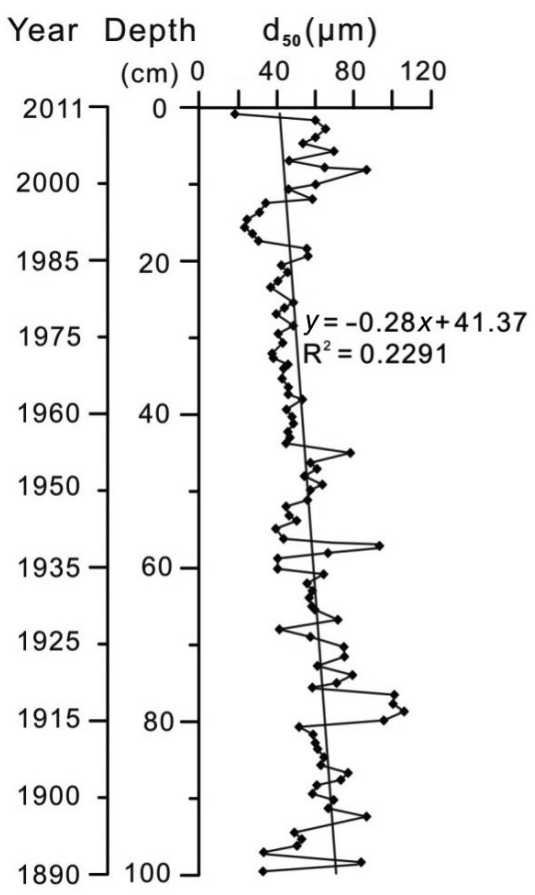

a
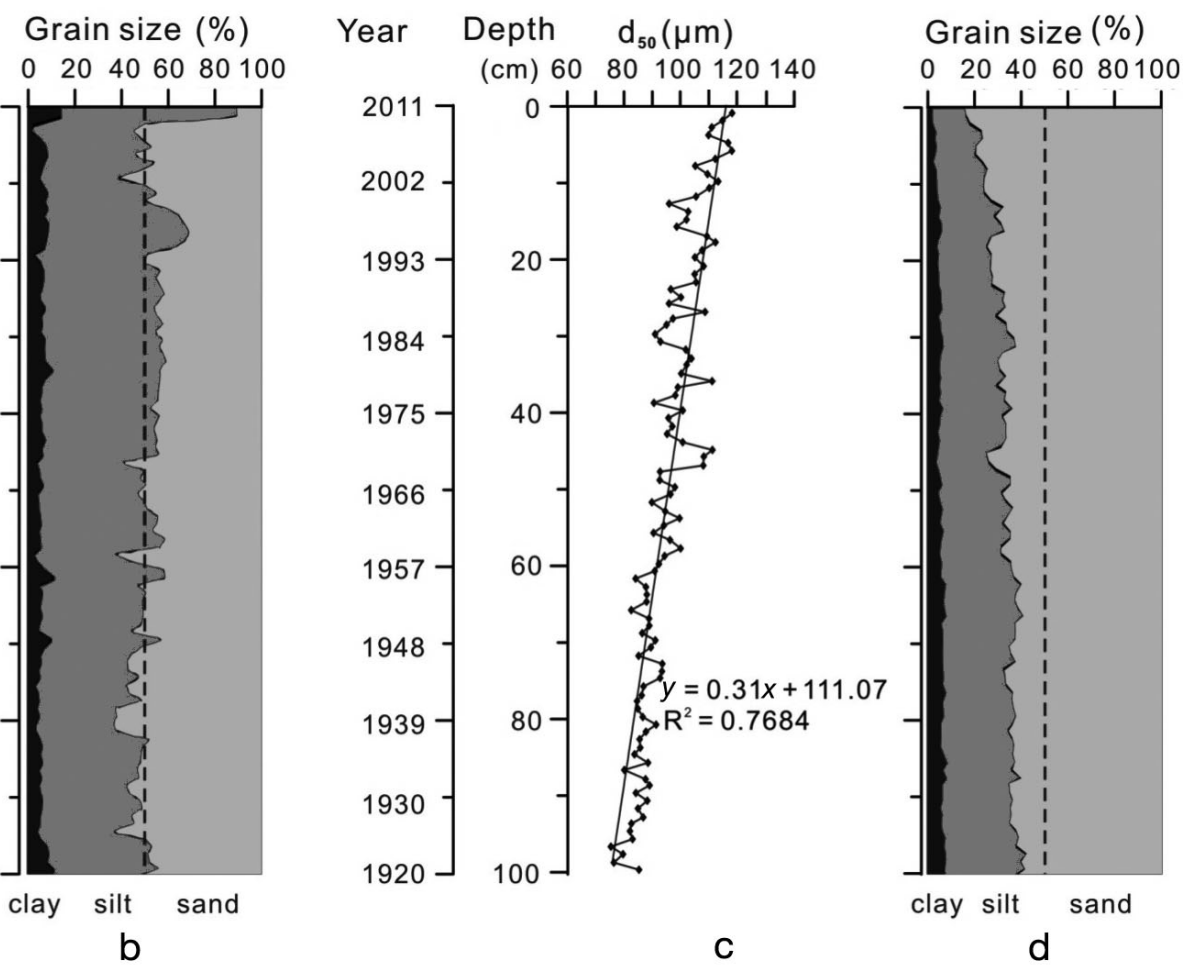

Fig. 4. Profiles of grain size for the sediment cores from $(a, b)$ Site 1 and $(c, d)$ Site 2, showing $(a, c)$ median values $\left(d_{50}\right)$ with linear trend and $(\mathrm{b}, \mathrm{d})$ the proportions of clay, silt, and sand

it is often difficult to find a distinct '1954 depth' in a mixed core (Johannessen \& Macdonald 2012). In this study, ${ }^{137} \mathrm{Cs}$ activity peaked at the core depth of $35 \mathrm{~cm}$ at Site 1 and $49 \mathrm{~cm}$ at Site 2 (Fig. 3b,d), corresponding to 1968 and 1967, respectively, in the ${ }^{210} \mathrm{~Pb}$ geochronology. This suggests that the calculated ${ }^{210} \mathrm{~Pb}$ geochronology was reasonable at the decadal scale.

\section{Grain size profiles at the two sites}

The median grain size $\left(\mathrm{d}_{50}\right)$ in the sediment cores varied within a range of 17.8 to $107.5 \mu \mathrm{m}$ at Site 1 (Fig. 4a) and 74.9 to $118.2 \mu \mathrm{m}$ at Site 2 (Fig. 4c), indicating that the sediment type was silty sand. This is consistent with previous studies carried out in King Sound and the Fitzroy River delta (Semeniuk 1981, Semeniuk \& Brocx 2011). In a spatial comparison, the variation in $d_{50}$ at the 2 sites showed opposite trends over time (Fig. 4a,c). At Site 1, finer particles (silt and clay) increased gradually and became evident in the upper section of the core ( $>50 \%$; Fig. $4 \mathrm{~b})$, whereas at Site 2, sediments became coarser with decreasing silt and clay, particularly in the upper section of the core $(<40 \%$; Fig. 4 d).

\section{Profiles of geochemical parameters at Site 1}

The chronological variations in TOC, TN, C:N, $\delta^{13} \mathrm{C}, \delta^{15} \mathrm{~N}$, and $\mathrm{BSi}$ in the sediment core from Site 1 are shown in Fig. 5. TOC concentrations ranged from 0.16 to $0.95 \%$, with an average of $0.35 \%$ (Fig. 5a), and TN varied between 0.01 and $0.11 \%$, with an average of $0.03 \%$ (Fig. 5b). Based on the STARS assessment, 2 dominant phases were identified in TOC and TN over time: (1) a relatively stable phase with only 1 shift change before the 1950s (at a depth of 55 to $100 \mathrm{~cm}$ ); and (2) a significantly variable phase with several increasing shift changes after the 1950s (at a depth of 0 to $55 \mathrm{~cm}$ ), particularly from the 1970 s to 2011 (in the top $35 \mathrm{~cm}$ ).

Two significant shifts in $\mathrm{C}: \mathrm{N}$ ratios and $\delta^{13} \mathrm{C}$ values were also observed after the 1950s (at a depth of approximately $50 \mathrm{~cm}_{i}$ Fig. $5 \mathrm{c}, \mathrm{d}$ ). C:N ratios (5 to 7 for marine-derived organic matter; Redfield et al. 1963; $>12$ for terrestrial-derived organic matter; Meyers 1997) shifted from a phase with terrigenous dominance (12.0 to 19.8 ; Fig. 5c) to a phase with a marine and terrestrial mixture (7.5 to 12.0 ; Fig. $5 \mathrm{c}$ ). $\delta^{13} \mathrm{C}$ values $(-19$ to $-21 \%$ for typical marine-derived organic carbon, and $-27.0 \%$ for typical river-derived terrigenous fraction; Fry \& Sherr 1984) increased from 


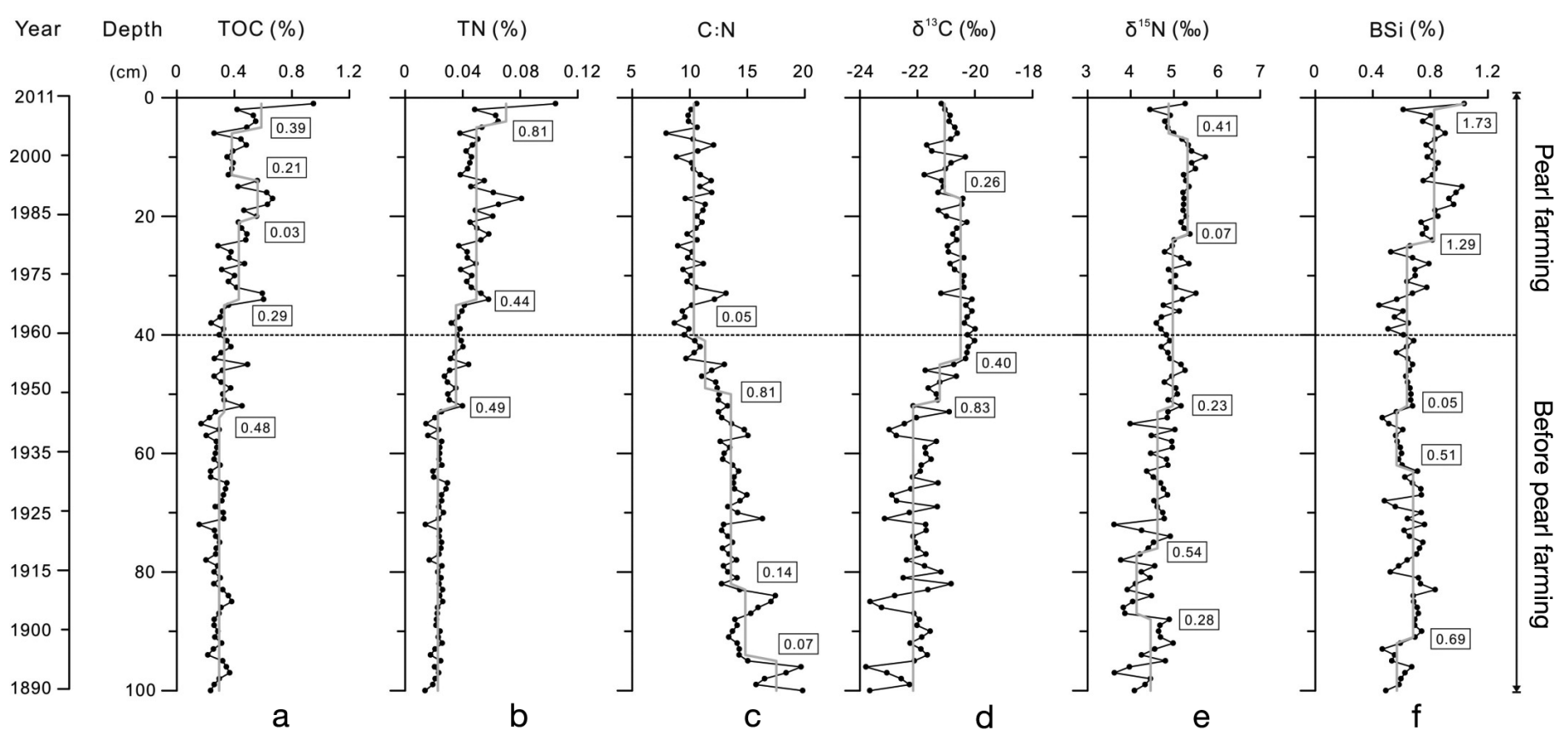

Fig. 5. Profiles of geochemical parameters for the sediment cores from Site 1. (a) Total organic carbon (TOC); (b) total nitrogen (TN); (c) C:N ratio; (d) $\delta^{13} \mathrm{C}_{i}$ (e) $\delta^{15} \mathrm{~N}_{\text {; }}$ (f) biogenic silica (BSi). Grey lines: shift changes assessed by sequential $t$-test analysis of regime shifts; values in solid squares: regime shift index

between -24 and $-22 \%$ to between -22 and $-20 \%$ at a depth of approximately $50 \mathrm{~cm}$ (Fig. 5d). The C:N ratio and $\delta^{13} \mathrm{C}$ trends indicated a significant increase in marine organic carbon.

$\delta^{15} \mathrm{~N}$ is used as a subsidiary factor to detect anthropogenically enriched organic nitrogen (McClelland \&Valiela 1998, Savage 2005), for example farm runoff, and animal and human waste. The values of $\delta^{15} \mathrm{~N}$ originating from typical marine nitrate generally fall into a range of 3 to $5 \%$ (Owens 1988). The values of $\delta^{15} \mathrm{~N}$ in the core ranged from 3.62 to $5.73 \%$ with a slight increasing trend (Fig. 5e), indicating a dominance of marine nitrate with low anthropogenic impact. BSi concentration in the core ranged from 0.44 to $1.04 \%$ (Fig. 5f) and displayed a significant increasing trend after the 1950s (at a depth of approximately 0 to $50 \mathrm{~cm}$ ), particularly from the 1970s to 2011 (in the top $35 \mathrm{~cm}$ ). The variations in BSi appear to match the increasing trends of TOC and TN.

\section{Profiles of geochemical parameters at Site 2}

The chronological variations in TOC, TN, C:N, $\delta^{13} \mathrm{C}, \delta^{15} \mathrm{~N}$, and BSi at Site 2 are shown in Fig. 6. TOC and TN contents (Fig. 6a,b) varied within a narrow range (TOC: 0.16 to $0.36 \%$; TN: 0.02 to $0.04 \%$ ), and the absolute values were much lower than at Site 1 (Fig. 5a,b). Based on the STARS assessment, both
TOC and TN showed increasing shift changes after the 1970s (at a depth of $40 \mathrm{~cm}$ ), and a significant increase occurred after the 2000s (at a depth of $10 \mathrm{~cm}$; Fig. 6a,b). The patterns of C:N ratios (9.0 to 19.0) and $\delta^{13} \mathrm{C}$ values $(-22.7$ to $-18.7 \%$ ) were similar those at Site 1 , shifting to a phase with increased marine organic matter after the 1950s (at a depth of approximately $60 \mathrm{~cm}$; Fig. 6c,d).

In the depth range of 0 to $60 \mathrm{~cm}$ (1950s to 2011), most $\delta^{15} \mathrm{~N}$ values were within 4 to $5 \%$, indicating a stable status with a dominance of marine nitrogen and very low anthropogenic derived nitrogen. However, there were some high values at the bottom of the core (1920s to 1940s; Fig. 6e), indicating a possible anthropogenic disturbance. BSi concentrations at Site 2 were much lower than those at Site 1, and most values were between 0.2 and $0.4 \%$, with decreasing shift changes at a depth of 0 to $60 \mathrm{~cm}$ (Fig. 6f).

\section{Magnitude of environmental change at the two sites}

The ratios of 4 chronological parameters ( $\mathrm{BSi}$, silt, TOC, and TN) between the 2 sites were processed by STARS (Fig. 7a-d), with the aim of making a spatial comparison to assess the magnitude of environmental change with and without pearl farming. Before pearl farming started in Cygnet Bay (ca. 1960), the 


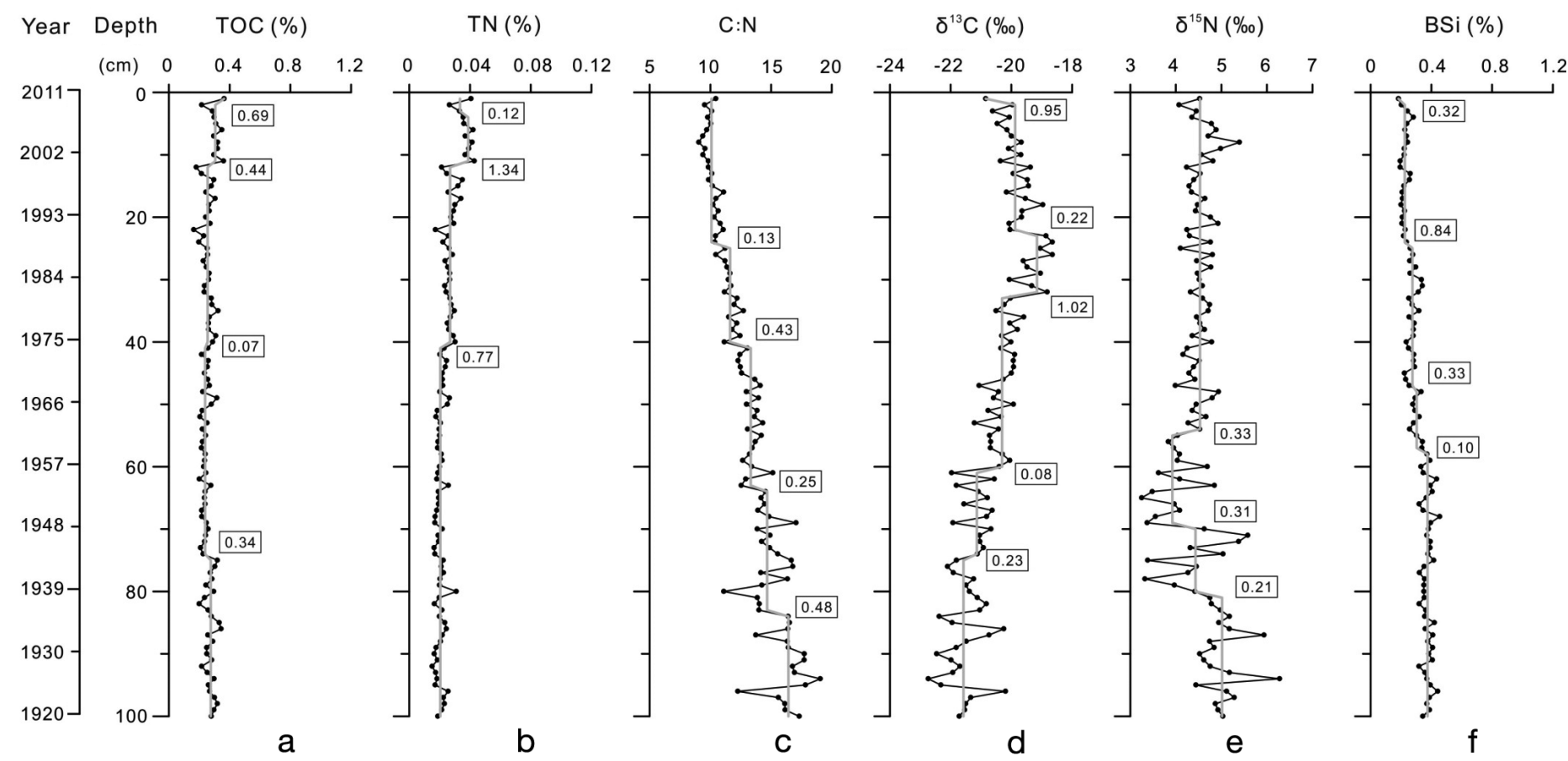

Fig. 6. Profiles of geochemical parameters for the sediment cores from Site 2. (a) Total organic carbon (TOC); (b) total nitrogen (TN); (c) C:N ratio; (d) $\delta^{13} C_{i}$ (e) $\delta^{15} \mathrm{~N}_{i}$ (f) biogenic silica (BSi). Grey lines: shift changes assessed by sequential $t$-test analysis of regime shifts; values in solid squares: regime shift index

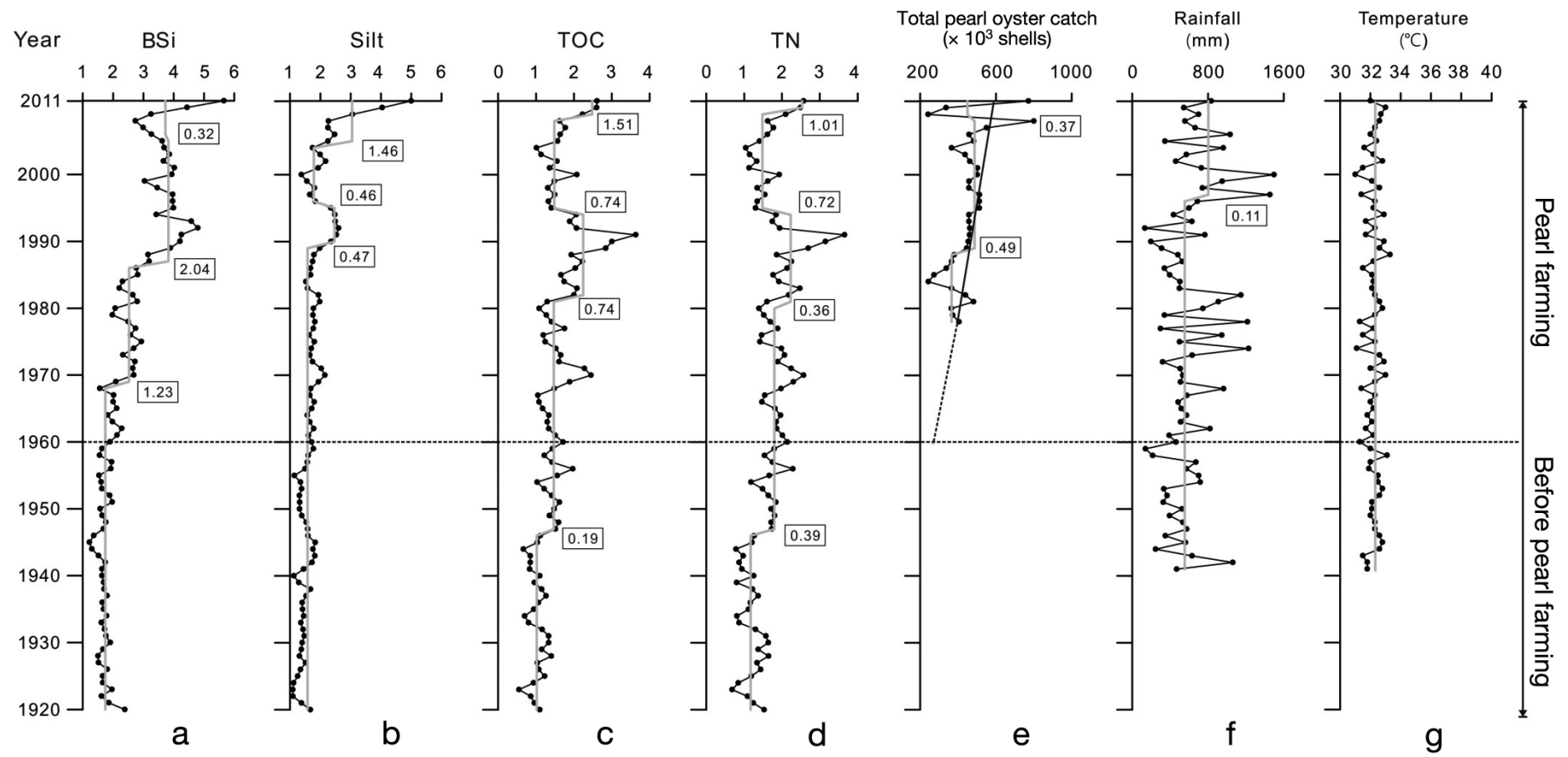

Fig. 7. Profiles of spatial comparisons between the 2 sites, based on the geochemical ratios of (a) biogenic silica (BSi); (b) silt; (c) total organic carbon (TOC); and (d) total nitrogen (TN). (e) Total pearl oyster catch in the Broome area from 1978 to 2011 (data from Hart et al. 2013), and (f) annual rainfall and (g) mean maximum temperature from 1941 to 2011 (data from Bureau of Meteorology 2014b). Grey lines: shift changes assessed by sequential $t$-test analysis of regime shifts; values in solid squares: 
variations in BSi and silt ratios were low and lacked a significant shift change (Fig. 7a,b). TOC and TN ratios showed similarly stable patterns except for small shift changes in the late 1940s (RSI: 0.19, 0.39; Fig. $7 \mathrm{c}, \mathrm{d}$ ). The results indicate that the 2 sites experienced similar environmental conditions with low variability before pearl farming.

After the commencement of pearl farming (since 1960), the ratios of the 4 parameters exhibited higher values and frequent shift changes, particularly after the 1980s (Fig. 7a-d). Significant increases in BSi ratios (RSI: 1.23, 2.04, and 0.32) occurred 3 times, corresponding to the 1960s, 1980s, and 2000s (Fig. 7a), respectively. The ratios of silt, TOC, and TN presented similar patterns (Fig. 7b-d): they all showed a first significant increase in the 1980s, and then shifted back to a relatively lower level in the late 1990s and early 2000s, followed by a sudden increase again in surface sediment after 2005. The results suggest that the magnitude of environmental change at Site 1 with pearl farming was much higher than that at Site 2 without pearl farming.

\section{DISCUSSION}

In this study, contrasting patterns in geochemical parameters between the 2 sites indicated that a faster environmental change occurred at Site 1 after the initiation of pearl oyster farming in the 1960s. The corresponding variations in the $\mathrm{C}: \mathrm{N}$ ratios, $\delta^{13} \mathrm{C}$, and $\delta^{15} \mathrm{~N}$ further suggested that increased TOC and TN in the upper section of the cores were mainly contributed by increased autochthonous rather than allochthonous input. In the following sections, we discuss the possible mechanisms of geochemical changes in the cores in relation to the history of pearl oyster farming and natural disturbance in Cygnet Bay, in order to provide a better understanding of the long-term environmental consequences of pearl oyster farming.

\section{Changes in grain size in response to pearl farming}

One of the environmental consequences of bivalve aquaculture is altered sediment properties, including reduced grain size and an increased concentration of organic matter (Mesnage et al. 2007, Hargrave et al. 2008, Dumbauld et al. 2009). For example, the incidental source of organic enrichment below bivalve culture apparatus has been recognized as important in a review of ecosystem effects of bivalve culture by the US National Academy of Sciences (Ocean Stud- ies Board 2010). Gaertner-Mazouni et al. (2012) estimated the sediment flux in Ahe Atoll lagoon (French Polynesia) using a sediment trap, and found that the sedimentation rates beneath the pearl oyster culture can be 5 times higher than in the control zone, and the percentage of small particles $(\leq 63 \mu \mathrm{m})$ was about double, although the impact of pearl farming is generally much lower than fish or other bivalve farming (Gifford et al. 2004, Yokoyama et al. 2006, Andréfouët et al. 2012).

The Brown family, who own and manage Cygnet Bay Pearls, indicated that the family started farming near Site 1 (bottom farming near Shenton Bluff reef) in 1960 at low density. Modern long-line culture was started in the 1980s, and stock levels and farm size ramped up appreciably through the 1990s. These changes are reflected in the total pearl oyster catch in the Broome area during 1978 to 2011 (Fig. 7e). In this study, fine-grained sediment (clay and silt) at Site 1 with pearl farming displayed significant increases after the 1960s (Fig. 4b), with an average increasing rate (ca. $0.2 \% \mathrm{yr}^{-1}$ ). The silt proportion at Site 1 was approximately 1 - to 5-fold higher than at Site 2 without farming (Fig. 7b), indicating a similar trend to that in Ahe Atoll lagoon. STARS detected a shift change in silt between the 2 sites in the late 1980s, which corresponds with the expansion of modern long-line culture at Site 1 since the 1980s (Fig. 7b,e). The organic waste produced by pearl farms, e.g. the deposition of feces and pseudo-feces from pearl oysters, and the debris fallout from the culture apparatus, including that produced during regular maintenance cleaning of the cages (Fig. 2), might be an important source of organic enrichment in the sediment. At Site 1, reduced grain size in the core over time matched the increases in TOC and TN organic matter well, displaying significantly positive correlations (see Table S1 in the Supplement at www.intres.com/articles/suppl/m552p145_supp.pdf).

In addition, it is necessary to consider the impact of modern long-line culture on the hydrodynamic processes in Cygnet Bay. Previous studies have indicated that the degree of sediment change mostly depends on the density of aquaculture relative to current speed (Plew et al. 2005, Richard et al. 2007). For example, the aquaculture density in New Zealand's coastal waters has reached 800 mussels $\mathrm{m}^{-1}$ of longline (Hartstein \& Rowden 2004). The average current speed is 0.4 to $0.5 \mathrm{~m} \mathrm{~s}^{-1}$ in the absence of farms, but this can be reduced by 36 to $63 \%$ within the farm, indicating a significant drag of mussel lines on currents and waves (Plew et al. 2005). However, this was previously not considered to be important in Cygnet 
Bay, because current speeds are fast in King Sound (average speed $>0.2 \mathrm{~m} \mathrm{~s}^{-1}$, maximum $0.75 \mathrm{~m} \mathrm{~s}^{-1}$; Wolanski \& Spagnol 2003). The pearl oyster industry in Australia is expanding at a considerable rate $(\mathrm{Ku}-$ chel et al. 2011), and there is a need to better understand the correlation between rate of environmental change and the intensity of pearl farming for longterm sustainable management.

\section{Changes in organic matter in response to pearl farming}

Like the variations in grain size, TOC and TN contents at Site 1 were higher and had more frequent shift changes than those at Site 2 after the 1980s (Figs. 5-7), corresponding to increased stock levels during the 1980s to 2000s (Fig. 7e). In contrast, TOC and TN contents at Site 2 only showed 2 slight shift changes (1970s and 2000s, Fig. 6a,b), which were in response to increased rainfall in this area (Fig. 7f: 30 to $40 \mathrm{~mm} 10 \mathrm{yr}^{-1}$ since the $1970 \mathrm{~s}$, and 40 to $50 \mathrm{~mm}$ $10 \mathrm{yr}^{-1}$ around the 2000s; Bureau of Meteorology 2014a, www.bom.gov.au/climate). However, the disturbance due to rainfall at Site 1 was obscured by the stronger impact of pearl farming (Fig. 5). Elevated carbon and nitrogen contents are generally evident in sediment after a period of aquaculture (Hatcher et al. 1994, Hargrave et al. 2008), but it was necessary to determine whether allochthonous input may have been an alternative explanation.

The three parameters $\mathrm{C}: \mathrm{N}$ ratio, $\delta^{13} \mathrm{C}$, and $\delta^{15} \mathrm{~N}$ have been used successfully for identifying organic matter source by several authors (e.g. Meyers 1994, Cifuentes et al. 1996, Bratton et al. 2003). Here, their patterns over time were very similar at the 2 sites (Figs. $5 \& 6$ ), indicating a shift in organic matter source from a phase dominated by terrestrial input to a phase with a marine and terrestrial mixture after the 1950s. The fate and source of organic matter before the 1950s is beyond the scope of this study, which is to identify the effect of pearl farming. In King Sound, the Fitzroy River is an important vector bringing terrestrial organic sources to the river delta and coastal embayment during the wet season, and buried mangrove materials in the high intertidal zone can also contribute to the terrestrial organic matter in mud (Semeniuk 1981). The distance and scale over which terrestrial organic matter is transported to the ocean are strongly related to tidal levels in this region, particularly for fine particles (Semeniuk 1981, Semeniuk \& Brocx 2011). At Site 2 without farming, the sediment grain size tended to become coarser over time, indicating a possible process of coastal erosion due to strong tidal action, which can change the ratio between marine and terrestrial inputs. However, this kind of sedimentary feature requires exploration of the long-term variation in oceanographic setting and climate change.

After the 1950s, most C:N and $\delta^{13} \mathrm{C}$ values at Site 1 were within the range of 6.7 to 10 and -22 to $-19 \%$, respectively, indicating that the increased organic carbon arose from marine phytoplankton (Meyers \& Teranes 2001, Lamb et al. 2006). Furthermore, the ranges of $\delta^{15} \mathrm{~N}$ in the cores were relatively stable, and most values were around $5 \%$ (Fig. 5), indicating that the dominant nitrogen source originated from marine nitrate (Owens 1988) with low impact from anthropogenically enriched organic nitrogen (McClelland \& Valiela 1998, Savage 2005). This is in accord with the fact that there are almost no pollution sources around Cygnet Bay due to the few towns and little anthropogenic activity, except for pearl farming. Therefore, we can confirm that the increased TOC and TN contents at Site 1 were mainly a consequence of pearl farming.

\section{Changes in BSi in response to pearl farming}

The phytoplankton of the shelf waters in NorthWest Australia is basically a diatom flora (Hallegraeff \& Jeffrey 1984), and diatoms in the sediment of King Sound are one of the important biogenesis contributors to mud-sized skeletons (Semeniuk 2011). Thus, this allows us to use BSi concentration in the sediment as a proxy to reflect the variations in diatom biomass in response to pearl farming. In this study, BSi concentrations at Site 1 were much higher than those at Site 2 after the 1970s (2.0 to 5.6 times; Fig. 7), and STARS detected a very significant increasing shift change in the 1980s (Fig. 5) corresponding to the development of long-line culture in the late 1980s and increased stock levels (Fig. 7e). These results matched the variations in $\mathrm{TOC}, \mathrm{TN}$, and sediment texture, and the indications from $\mathrm{C}: \mathrm{N}$ and $\delta^{13} \mathrm{C}$ values, suggesting that pearl farming promoted the growth of phytoplankton, at least for diatoms. From this study, we cannot determine whether the enhancement of diatoms by pearl farming reflected in our samples is a result of predominantly enhanced benthic (elongate or chain-forming) diatom deposition or whether water column (mainly centric) diatoms were also enhanced. This would require an assessment of the distribution of diatom fossils throughout the sediment profile in a future study. 
Modification of trophic status, for example increased nutrient concentration and phytoplankton biomass, was observed in a coastal embayment with a decadal history of aquaculture (Pusceddu et al. 2009, Sarà et al. 2011). Low density pearl farming can create a mutually beneficial environment for the growth of phytoplankton and pearl oysters, which has been examined in Gokasho Bay, Japan (Abo \& Toda 2001). The excretion of pearl oysters and other organic wastes can provide nutrients, and the reduced water flow can prolong residence time and create a favorable environment for phytoplankton growth. Additionally, the increased TN in the sediment can enhance nitrogen flux and recycling in the water column. For example, in the Ahe Atoll lagoon (French Polynesia), benthic nitrogen fluxes in the pearl oyster farming area could sometimes contribute up to $28 \%$ of the nitrogen demand for primary production (Gaertner-Mazouni et al. 2012). Meanwhile, increased phytoplankton biomass is good for the growth of pearl oysters.

During 1940 to 2011 in King Sound, STARS detected a significant increase in annual rainfall after 1997 (Fig. 7f), with an increase of approximately 40 to $50 \mathrm{~mm} 10 \mathrm{yr}^{-1}$. Mean maximum temperatures varied between 31 and $33^{\circ} \mathrm{C}$, with a statistically insignificant increase of approximately 0.05 to $0.1^{\circ} \mathrm{C} 10 \mathrm{yr}^{-1}$ (Fig. 7g). These changes might impact on diatom biomass (Beaugrand \& Reid 2003, Barbosa et al. 2010). However, BSi concentrations at Site 2 displayed a decreasing trend with several small shift changes (Fig. 6f), and this was not consistent with the response of TOC and TN contents to increased rainfall. The opposing variations in BSi concentrations at the 2 sites indicate that the impact of pearl farming on diatom growth was much greater than that of rainfall and temperature.

\section{CONCLUSION}

In this study, the spatial comparison of multiple proxies (grain size, TOC, TN, BSi, C:N ratio, $\delta^{13} \mathrm{C}$, and $\delta^{15} \mathrm{~N}$ ) in sediment cores revealed decadal environmental effects of pearl farming, including alteration of sediment texture and increases in organic matter and diatom biomass. Although sediment quality in King Sound did not reach a eutrophic level (Wells \& Jernakoff 2006, McCallum \& Prince 2009, Jelbart et al. 2011), the increasing rates of organic matter in sediment were much faster than those due to natural processes. One possible option to manage the rate of environmental change could be to dispose of the waste from the cleaning of the culture apparatus on land. This was recommended in a recent review (Ocean Studies Board 2010) to enhance the ecosystem sustainability of bivalve culture and this measure is also recommended as a way of reducing the potential of invasive species becoming established in bivalve farming areas.

Acknowledgements. This work was sponsored by the Natural Science Foundation of China (41376121), the Strategic Priority Research Program of the Chinese Academy of Sciences (XDA11020405) and the Natural Science Foundation of Shandong Province (JQ201414). It was funded in part by the Western Australian Marine Science Institution and the CSIRO. The authors thank James Brown and Ali McCarthy of Cygnet Bay Pearls for their assistance with field work and for sharing their knowledge of the history of pearl farming in Cygnet Bay. Anonymous reviewers and Dr. Charles Peterson provided helpful comments which improved the manuscript.

\section{LITERATURE CITED}

Abo K, Toda S (2001) Evaluation model of farming density of Japanese pearl oyster, Pinctada fucatamartensii, based on physiology and food environment. Bull Jpn Soc Fish Oceanogr Tokyo 65:4135-4144

Amos KJ, Croke JC, Timmers H, Owens PN, Thompson C (2009) The application of caesium-137 measurements to investigate floodplain deposition in a large semi-arid catchment in Queensland, Australia: a low-fallout environment. Earth Surf Process Landf 34:515-529

Andersen JH, Conley DJ, Hedal S (2004) Palaeoecology, reference conditions and classification of ecological status: the EU Water Framework Directive in practice. Mar Pollut Bull 49:283-290

Andersen T, Carstensen J, Hernàndez-García E, Duarte CM (2009) Ecological thresholds and regime shifts: approaches to identification. Trends Ecol Evol 24:49-57

Andréfouët S, Charpy L, Lo-Yat A, Lo C (2012) Recent research for pearl oyster aquaculture management in French Polynesia. Mar Pollut Bull 65:407-414

- Andrews JE, Greenaway AM, Dennis PF (1998) Combined carbon isotope and $\mathrm{C} / \mathrm{N}$ ratios as indicators of source and fate of organic matter in a poorly flushed, tropical estuary: Hunts Bay, Kingston Harbour, Jamaica. Estuar Coast Shelf Sci 46:743-756

Appleby PG (2001) Chronostratigraphic techniques in recent sediments. In: Last WM, Smol JP (eds) Tracking environmental change using lake sediments, Vol 1. Basin analysis, coring, and chronological techniques. Kluwer Academic Publishers, Dordrecht, p 171-203

Australian Bureau of Statistics (2011) Census QuickStats. www.censusdata.abs.gov.au/census_services/getproduct/ census/2011/quickstat/UCL515008?opendocument\&nav pos $=220$

Barbosa AB, Domingues RB, Galvão HM (2010) Environmental forcing of phytoplankton in a Mediterranean estuary (Guadiana Estuary, South-western Iberia): a decadal study of anthropogenic and climate influences. Estuaries Coasts 33:324-341

Beaugrand G, Reid PC (2003) Long-term changes in phyto- 
plankton, zooplankton and salmon related to climate. Glob Change Biol 9:801-817

- Bernárdez P, Prego R, Francés G, González-Álvarez R (2005) Opal content in the Ría de Vigo and Galician continental shelf: biogenic silica in the muddy fraction as an accurate paleoproductivity proxy. Cont Shelf Res 25:1249-1264

Bratton JF, Colman SM, Seal RR (2003) Eutrophication and carbon sources in Chesapeake Bay over the last $2700 \mathrm{yr}$ : human impacts in context. Geochim Cosmochim Acta 67: 3385-3402

Bureau of Meteorology (2014a) Australian climate average conditions - average conditions maps. www.bom.gov. au/climate/averages/maps.shtml

Bureau of Meteorology (2014b) Australian climate data online (Station: Broome Airport; Station number: 003003). www.bom.gov.au/climate/data/?ref=ftr

Callier MD, McKindsey CW, Desrosiers G (2008) Evaluation of indicators used to detect mussel farm influence on the benthos: two case studies in the Magdalen Islands, Eastern Canada. Aquaculture 278:77-88

CENRM (Centre of Excellence in Natural Resource Management) (2010) Fitzroy River catchment management plan. University of Western Australia, Perth

Cheney DP, Haws MC, Ponia BE, Thomforde HW (1995) Ecological characterization and environmental monitoring in conjunction with pearl farming of the Tongareva Lagoon, Cook Islands. Aquaculture 95. Proc World Aquacult Soc Meeting, Feb 1995, National Shellfisheries Association, San Diego, CA (abstract)

Cifuentes LA, Coffin RB, Solorzano L, Cardenas W, Espinoza J, Twilley RR (1996) Isotopic and elemental variation of carbon and nitrogen in a mangrove estuary. Estuar Coast Shelf Sci 43:781-800

da Costa KG, Nalesso RC (2006) Effects of mussel farming on macrobenthic community structure in Southeastern Brazil. Aquaculture 258:655-663

> Dale B (2009) Eutrophication signals in the sedimentary record of dinoflagellate cysts in coastal waters. J Sea Res 61:103-113

> DeMaster DJ (2002) The accumulation and cycling of biogenic silica in the Southern Ocean: revisiting the marine silica budget. Deep-Sea Res II 49:3155-3167

> DeMaster DJ, Nelson TM, Harden SL, Nittrouer CA (1991) The cycling and accumulation of biogenic silica and organic carbon in Antarctic deep-sea and continental margin environments. Mar Chem 35:489-502

> Dumbauld BR, Ruesink JL, Rumrill SS (2009) The ecological role of bivalve shellfish aquaculture in the estuarine environment: A review with application to oyster and clam culture in West Coast (USA) estuaries. Aquaculture 290:196-223

Folk RL, Andrews PB, Lewis DW (1970) Detrital sedimentary rock classification and nomenclature for use in New Zealand. NZ J Geol Geophys 13:937-968

Forrest BM, Keeley NB, Hopkins G, Webb SC, Clement DM (2009) Bivalve aquaculture in estuaries: review and synthesis of oyster cultivation effects. Aquaculture 298:1-15

Fry B, Sherr EB (1984) $\delta^{13} \mathrm{C}$ measurements as indicators of carbon flow in marine and freshwater ecosystems. Mark Sci 27:13-47

> Gaertner-Mazouni N, Lacoste E, Bodoy A, Peacock L and others (2012) Nutrient fluxes between water column and sediments: potential influence of the pearl oyster culture. Mar Pollut Bull 65:500-505

Gifford S, Dunstan RH, O'Connor W, Roberts T, Toia R
(2004) Pearl aquaculture-profitable environmental remediation? Sci Total Environ 319:27-37

Hallegraeff GM, Jeffrey SW (1984) Tropical phytoplankton species and pigments of continental shelf waters of North and North-West Australia. Mar Ecol Prog Ser 20:59-74

Hargrave BT, Doucette LI, Cranford PJ, Law BA, Milligan TG (2008) Influence of mussel aquaculture on sediment organic enrichment in a nutrient-rich coastal embayment. Mar Ecol Prog Ser 365:137-149

Hart A, Murphy D, Jones R (2013) Pearl oyster managed fishery status report. In: Fletcher WJ, Santoro K (eds) Status reports of the fisheries and aquaculture resources of Western Australia 2013/14. State of the fisheries. Department of Fisheries, Perth, p 213-218

> Hartstein ND, Rowden AA (2004) Effect of biodeposits from mussel culture on macroinvertebrate assemblages at sites of different hydrodynamic regime. Mar Environ Res 57:339-357

Hatcher A, Grant J, Schofield B (1994) Effects of suspended mussel culture (Mytilus spp.) on sedimentation, benthic respiration and sediment nutrient dynamics in a coastal bay. Mar Ecol Prog Ser 115:219-235

> Hollins SE, Harrison JJ, Jones BG, Zawadzki A, Heijnis H, Hankin S (2011) Reconstructing recent sedimentation in two urbanised coastal lagoons (NSW, Australia) using radioisotopes and geochemistry. J Paleolimnol 46: 579-596

> Jelbart JE, Schreider M, MacFarlane GR (2011) An investigation of benthic sediments and macrofauna within pearl farms of Western Australia. Aquaculture 319:466-478

Johannessen SC, Macdonald RW (2012) There is no 1954 in that core! Interpreting sedimentation rates and contaminant trends in marine sediment cores. Mar Pollut Bull 64: 675-678

Kamatani A, Oku O (2000) Measuring biogenic silica in marine sediments. Mar Chem 68:219-229

Kishore P, Hunter J, Zeng C, Southgate PC (2014) The effects of different culture apparatuses and current velocities on byssus production by the black-lip pearl oyster, Pinctada margaritifera. Aquaculture 434:74-77

Krause JW, Nelson DM, Brzezinski MA (2011) Biogenic silica production and the diatom contribution to primary production and nitrate uptake in the eastern equatorial Pacific Ocean. Deep-Sea Res II 58:434-448

> Kuchel RP, O' Connor WA, Raftos DA (2011) Environmental stress and disease in pearl oysters, focusing on the Akoya pearl oyster (Pinctada fucata Gould 1850). Rev Aquacult 3:138-154

Kuwae M, Yamaguchi H, Tsugeki NK, Miyasaka H and others (2006) Spatial distribution of organic and sulfur geochemical parameters of oxic to anoxic surface sediments in Beppu Bay in southwest Japan. Estuar Coast Shelf Sci 72:1-11

Lamb AL, Wilson GP, Leng MJ (2006) A review of coastal palaeoclimate and relative sea-level reconstructions using $\delta^{13} \mathrm{C}$ and $\mathrm{C} / \mathrm{N}$ ratios in organic material. Earth Sci Rev 75:29-57

Lees K, Pitois S, Scott C, Frid C, Mackinson S (2006) Characterizing regime shifts in the marine environment. Fish Fish 7:104-127

Liu D, Shen X, Di B, Shi Y, Keesing JK, Wang Y, Wang Y (2013) Palaeoecological analysis of phytoplankton regime shifts in response to coastal eutrophication. Mar Ecol Prog Ser 475:1-14

Logan B, Taffs KH, Eyre BD, Zawadski A (2011) Assessing 
changes in nutrient status in the Richmond River estuary, Australia, using paleolimnological methods. J Paleolimnol 46:597-611

McCallum B, Prince J (2009) Final report 2005/044. Development of the scientific requirements of an Environmental Management System (EMS) for the pearling (Pinctada maxima) industry. Fisheries Research and Development Corporation, Mt Hawthorn, WA

McClelland JW, Valiela I (1998) Linking nitrogen in estuarine producers to land derived sources. Limnol Oceanogr 43:577-585

Mesnage V, Ogier S, Bally G, Disnar J and others (2007) Nutrient dynamics at the sediment-water interface in a Mediterranean lagoon (Thau, France): influence of biodeposition by shellfish farming activities. Mar Environ Res 63:257-277

Meyers PA (1994) Preservation of elemental and isotopic source identification of sedimentary organic matter. Chem Geol 114:289-302

> Meyers PA (1997) Organic geochemical proxies of paleoceanographic, paleolimnologic, and paleoclimatic processes. Org Geochem 27:213-250

Meyers PA, Teranes JL (2001) Sediment organic matter. In: Last WM, Smol JP (eds) Tracking environmental change using lake sediments. Developments in paleoenvironmental research, Vol 2. Physical and geochemical methods. Kluwer Academic Publishers, Dordrecht, p 239-269

Ocean Studies Board (2010) Ecosystem concepts for sustainable bivalve mariculture. National Academies Press, Washington DC

Owens NJP (1988) Natural variations in ${ }^{15} \mathrm{~N}$ in the marine environment. Adv Mar Biol 24:389-451

> Pancost RD, Boot CS (2004) The palaeoclimatic utility of terrestrial biomarkers in marine sediments. Mar Chem 92: 239-261

> Pfitzner J, Brunskill G, Zagorskis I (2004) ${ }^{137}$ Cs and excess ${ }^{210} \mathrm{~Pb}$ deposition patterns in estuarine and marine sediment in the central region of the Great Barrier Reef Lagoon, north-eastern Australia. J Environ Radioact 76: 81-102

> Plew DR, Stevens CL, Spigel RH, Hartstein ND (2005) Hydrodynamic implications of large offshore mussel farms. IEEE J Oceanic Eng 30:95-108

Prins TC, Smaal AC (1994) The role of the blue mussel Mytilus edulis in the cycling of nutrients in the Oosterschelde estuary (The Netherlands). Hydrobiologia 282283:413-429

Pusceddu A, Dell'Anno A, Fabiano M, Danovaro R (2009) Quantity and bioavailability of sediment organic matter as signatures of benthic trophic status. Mar Ecol Prog Ser 375:41-52

Read P, Fernandes T (2003) Management of environmental impacts of marine aquaculture in Europe. Aquaculture 226:139-163

Redfield AC, Ketehum BH, Richards EA (1963) The influence of organisms on the composition of seawater. In: Hill MN (ed) The sea, Vol 2. Interscience, New York, NY, p 26-77

Richard M, Archambault P, Thouzeau G, McKindsey CW, Desrosiers G (2007) Influence of suspended scallop cages and mussel lines on pelagic and benthic biogeochemical fluxes in Havre-aux-Maisons Lagoon, Îles-de-la-Made-

Editorial responsibility: Charles Peterson,

Morehead City, North Carolina, USA laine (Quebec, Canada). Can J Fish Aquat Sci 64: 1491-1505

Rodionov S (2004) A sequential algorithm for testing climate regime shifts. Geophys Res Lett 31, L09204, doi:10.1029/ 2004GL019448

Rodionov S, Overland JE (2005) Application of a sequential regime shift detection method to the Bering Sea ecosystem. ICES J Mar Sci 62:328-332

- Ruiz-Fernández AC, Hillaire-Marcel C (2009) ${ }^{210} \mathrm{~Pb}$-derived ages for the reconstruction of terrestrial contaminant history into the Mexican Pacific coast: potential and limitations. Mar Pollut Bull 59:134-145

Sarà G, Lo Martire M, Sanfilippo M, Pulicanò G and others (2011) Impacts of marine aquaculture at large spatial scales: evidence from $\mathrm{N}$ and $\mathrm{P}$ catchment loading and phytoplankton biomass. Mar Environ Res 71:317-324

Savage C (2005) Tracing the influence of sewage nitrogen in a coastal ecosystem using stable nitrogen isotopes. Ambio 34:145-150

Semeniuk V (1981) Sedimentology and the stratigraphic sequence of a tropical tidal flat, north-western Australia. Sediment Geol 29:195-221

Semeniuk V (2011) Stratigraphic patterns in coastal sediment sequences in the Kimberley region, Western Australia: products of coastal form, oceanographic setting, sedimentary suites, sediment supply, and biogenesis. J R Soc West Aust 94:133-150

Semeniuk V, Brocx M (2011) King Sound and the tidedominated delta of the Fitzroy River: their geoheritage values. J R Soc West Aust 94:151-160

Smith JN (2001) Why should we believe ${ }^{210} \mathrm{~Pb}$ sediment geochronologies? J Environ Radioact 55:121-123

Smol JP, Stoermer EF (2010) Applications and uses of diatoms: prologue. In: Smol JP, Stoermer EF (eds) The diatoms: applications for the environmental and earth sciences. Cambridge University Press, New York, NY, p 3-7

Strang TJ (2003) Nutrient regeneration under mussel farms: the environmental effects of mussel aquaculture in coastal bays. MSc thesis, Memorial University of Newfoundland, St. John's

Tisdell C, Poirine B (2008) Economics of pearl farming. In: Southgate PC, Lucas JS (eds) The pearl oyster. Elsevier, Oxford, p 473-495

Turner RE, Rabalais NN, Fry B, Atilla N and others (2006) Paleo-indicators and water quality change in the Charlotte Harbor estuary (Florida). Limnol Oceanogr 51: 518-533

> Wells FE, Jernakoff P (2006) An assessment of the environmental impact of wild harvest pearl aquaculture (Pinctada maxima) in Western Australia. J Shellfish Res 25: 141-150

Wolanski E, Spagnol S (2003) Dynamics of the turbidity maximum in King Sound, tropical Western Australia. Estuar Coast Shelf Sci 56:877-890

Yokoyama H (2002) Impact of fish and pearl farming on the benthic environments in Gokasho Bay: evaluation from seasonal fluctuations of the macrobenthos. Fish Sci 68: 258-268

Yokoyama H, Abo K, Ishihi Y (2006) Quantifying aquaculture-derived organic matter in the sediment in and around a coastal fish farm using stable carbon and nitrogen isotope ratios. Aquaculture 254:411-425

Submitted: April 16, 2015; Accepted: April 21, 2016

Proofs received from author(s): June 7, 2016 